\title{
Serotonin receptors and suicide, major depression, alcohol use disorder and reported early life adversity
}

\author{
Mark D. Underwood ${ }^{1,2}$, Suham A. Kassir ${ }^{2}$, Mihran J. Bakalian (1) ${ }^{2}$, Hanga Galfalvy ${ }^{1,2,3}$, Andrew J. Dwork ${ }^{1,2,4,5}$, \\ J. John Mann ${ }^{1,2}$ and Victoria Arango $0^{1,2}$
}

\begin{abstract}
Serotonin neurotransmitter deficits are reported in suicide, major depressive disorder (MDD) and alcohol use disorder (AUD). To compare pathophysiology in these disorders, we mapped brain serotonin transporter (SERT), 5-HT ${ }_{1 A}$, and 5$\mathrm{HT}_{2 \mathrm{~A}}$ receptor binding throughout prefrontal cortex and in anterior cingulate cortex postmortem. Cases and controls died suddenly minimizing agonal effects and had a postmortem interval $\leq 24 \mathrm{~h}$ to avoid compromised brain integrity. Neuropathology and toxicology confirmed absence of neuropathology and psychotropic medications. For most subjects (167 of 232), a DSM-IV Axis I diagnosis was made by psychological autopsy. Autoradiography was performed in right hemisphere coronal sections at a pre-genual level. Linear model analyses included sex and age with group and Brodmann area as interaction terms. SERT binding was lower in suicides $(p=0.004)$ independent of sex (females $<$ males, $p<0.0001)$, however, the lower SERT binding was dependent on MDD diagnosis $(p=0.014)$. Higher SERT binding was associated with diagnosis of alcoholism $(p=0.012)$. $5-\mathrm{HT}_{1 \mathrm{~A}}$ binding was greater in suicides $(p<0.001)$, independent of $\operatorname{MDD}(p=0.168)$. Alcoholism was associated with higher $5-\mathrm{HT}_{1 \mathrm{~A}}$ binding $(p<0.001)$ but only in suicides $(p<0.001)$. $5-\mathrm{HT}_{2 \mathrm{~A}}$ binding was greater in suicides $(p<0.001)$ only when including $\operatorname{MDD}(p=0.117)$ and alcoholism $(p=0.148)$ in the model. Reported childhood adversity was associated with higher SERT and 5-HT $1 \mathrm{~A}$ binding $(p=0.004)$ in nonsuicides and higher $5-\mathrm{HT}_{2 \mathrm{~A}}$ binding $(p<0.001)$. Low SERT and more $5-\mathrm{HT}_{1 \mathrm{~A}}$ and $5-\mathrm{HT}_{2 \mathrm{~A}}$ binding in the neocortex in depressed suicides is dependent on Axis I diagnosis and reported childhood adversity. Findings in alcoholism differed from those in depression and suicide indicating a distinct serotonin system pathophysiology.
\end{abstract}

\section{Introduction}

Impaired serotonin (5-HT) neurotransmission is detectable in the brain of suicide decedents and in the cerebrospinal (CSF) fluid of nonfatal suicide attempters ${ }^{1,2}$, major depressive disorder (MDD) and alcohol use disorder $(\mathrm{AUD})^{3,4}$. Biological findings in suicide include those related to comorbid diagnoses and those associated

\footnotetext{
Correspondence: Mark D. Underwood (mu20@cumc.columbia.edu)

${ }^{1}$ Department of Psychiatry, Columbia University College of Physicians and

Surgeons, New York, NY, USA

${ }^{2}$ Division of Molecular Imaging and Neuropathology, Columbia University and New York State Psychiatric Institute, New York, NY, USA

Full list of author information is available at the end of the article.

These authors contributed equally: Victoria Arango, Mark D. Underwood
}

with the diathesis for suicide that explains why only a subgroup of people with MDD or AUD are at elevated risk for suicide ${ }^{5,6}$. Despite the fact that suicide-associated conditions such as MDD and AUD are frequently comorbid, little work has compared 5-HT receptor abnormalities in suicide, MDD, and AUD (see ref. ${ }^{1}$ for review).

Childhood adversity increases the risk of suicide, MDD, and AUD in adulthood ${ }^{7,8}$. What mediates the effect of childhood adversity on the risk for these diagnoses is not well understood, but epigenetic and gene-environment interactions are reported $^{9-11}$. We hypothesize that childhood adversity affects the serotonin system and 
contributes to increased risk for suicide, MDD or AUD in adulthood.

In vivo and in vitro imaging of the SERT and 5-HT receptor subtype binding in suicide and nonfatal suicide suggest there are serotonin system abnormalities; but there is less agreement about the direction of the findings, the specificity of the findings for each of these conditions, including which brain areas are involved ${ }^{12-22}$. Explanations for discrepant results include small effect sizes, variability in outcome measures, and biodemographic variability related to sex and age; other factors are the heterogeneity in suicide behavior and the effects from comorbid psychiatric disorders. Abnormalities in the serotonin system are more pronounced with more lethal suicidal behavior ${ }^{16,22-25}$. In the present study, we sought to determine the effects of suicide on serotonin receptor binding and separate the effects of suicide from comorbid MDD, AUD, and early life adversity studying postmortem brain using quantitative autoradiography, in the hitherto largest published sample of postmortem suicides and controls.

\section{Materials and methods \\ Subjects}

The Division of Molecular Imaging and Neuropathology at the New York State Psychiatric Institute was the source of the brain samples. The Institutional Review Boards of the appropriate Institutions approved all procedures. Subjects had postmortem intervals (PMI) of $24 \mathrm{~h}$ or less and died suddenly. The Coroner or Medical Examiner diagnosed suicides on the basis of evidence of intent and a self-inflicted fatal act. There were 232 cases total (Table 1): suicide decedents $(n=83)$ and nonsuicides $(n=149)$. The majority of the cases and controls used have been published elsewhere in smaller, focused studies $^{4,26-31}$.

The next-of-kin of 167 subjects (Table 2) agreed to a psychological autopsy interview ${ }^{32}$. We fully implemented the psychological autopsy protocol only after the first 65 suicides and nonsuicides had been collected. Diagnoses were based on DSM-IV criteria and used the Structured Clinical Interview for DSM (SCID-I and SCID-II ${ }^{33}$ ), and the Brown-Goodwin Aggression History Scale ${ }^{34}$. AUD diagnosis was based on the psychological autopsy and autopsy findings such as liver cirrhosis combined with a blood or brain alcohol level of $>0.15 \%$. Medication use within three months of death were recorded and recent use was confirmed by toxicology. All diagnoses, or lack thereof for controls, were made at a consensus conference with experienced psychiatrists, psychologists and other researchers. In the 232 cases, 65 subjects did not have a psychological autopsy, but we were able to review charts and other medical examiner records and arrive at a consensus diagnosis. 


\section{Brain collection}

After brain removal, the brainstem was separated by a transverse cut at the rostral margin of the superior colliculus. The cerebellum was removed by severing the peduncles. The brain was bisected and the right hemicerebrum was cut into $2 \mathrm{~cm}$-thick coronal slabs. The slabs were placed on a glass plate, frozen in liquid Freon 12 (DuPont), placed in labeled plastic bags and transferred to a $-80^{\circ} \mathrm{C}$ freezer. Cerebellar tissue was collected for genetics and brain toxicology. The left hemisphere was placed in formalin for neuropathology.

\section{Receptor autoradiography}

Quantitative in vitro receptor autoradiography was done on frozen tissue sections as described elsewhere ${ }^{26,27}$. A single concentration of ligand was used which was based on the $K_{d}$ reported in the literature and verified previously in our laboratories ${ }^{26,28}$. In brief, $20 \mu \mathrm{m}$ sections were used for $\left[{ }^{3} \mathrm{H}\right]$ Cyanoimipramine, $\left[{ }^{3} \mathrm{H}\right] 8-\mathrm{OH}-\mathrm{DPAT}$ and $\left[{ }^{3} \mathrm{H}\right]$ Ketanserin binding, to label SERT sites, $5-\mathrm{HT}_{1 \mathrm{~A}}$ and $5-\mathrm{HT}_{2 \mathrm{~A}}$ receptors, respectively (Fig. 1 ). Six tissue sections were used for each assay, three for total binding and three adjacent sections for non-specific binding. Sections were preincubated in buffer to remove endogenous ligands and incubated with radioligand under optimal conditions. Nonspecific binding was determined by incubation with appropriate displacers. Sections were then washed in buffer $\left(4^{\circ} \mathrm{C}\right)$, dipped in water, rapidly dried and transferred to a vacuum desiccator until exposure $(24 \mathrm{~h})$.

Dried slides were exposed to tritium-sensitive film (Hyperfilm from Amersham, or MS film from Kodak). Each film was exposed with tritium standards (American Radiolabeled Chemicals, Inc.). Films were developed (Kodak D-19) for $4 \mathrm{~min}$ at $17^{\circ} \mathrm{C}$, rinsed briefly, and fixed (Kodak Rapid Fixer) for 5 min The sections were fixed in buffered formalin and stained with thionin or cresyl violet.

Autoradiograms were quantified using an image analysis system (MCID, Imaging Research, Inc.). Images of standards were calibrated to femtomoles of radioligand per milligram of tissue. Samples of receptor binding were averaged from three sections to produce one binding measure for that individual.

(a) $\left[{ }^{3} \mathrm{H}\right]$ Cyanoimipramine (CN-IMI) binding to serotonin transporter sites: Total SERT binding was determined with $0.4 \mathrm{nM}{ }^{3} \mathrm{H}-\mathrm{CN}$-IMI and nonspecific binding using $10 \mu \mathrm{M}$ sertraline ${ }^{26}$.

(b) $\left[{ }^{3} \mathrm{H}\right] 8-\mathrm{OH}-\mathrm{DPAT}$ binding to $5-\mathrm{HT}_{1 \mathrm{~A}}$ receptors: 5$\mathrm{HT}_{1 \mathrm{~A}}$ receptors were measured using our modifications of the protocol of Hoyer et al. ${ }^{35}$. Slides were incubated with $2 \mathrm{nM}\left[{ }^{3} \mathrm{H}\right] 8-\mathrm{OH}-\mathrm{DPAT}$ and $100 \mathrm{nM}$ sertraline (to block SERT sites).

(c) $\left[{ }^{3} \mathrm{H}\right]-$ Ketanserin (Ket) binding to $5-\mathrm{HT}_{2 \mathrm{~A}}$ receptors: Total binding was determined by incubation with 


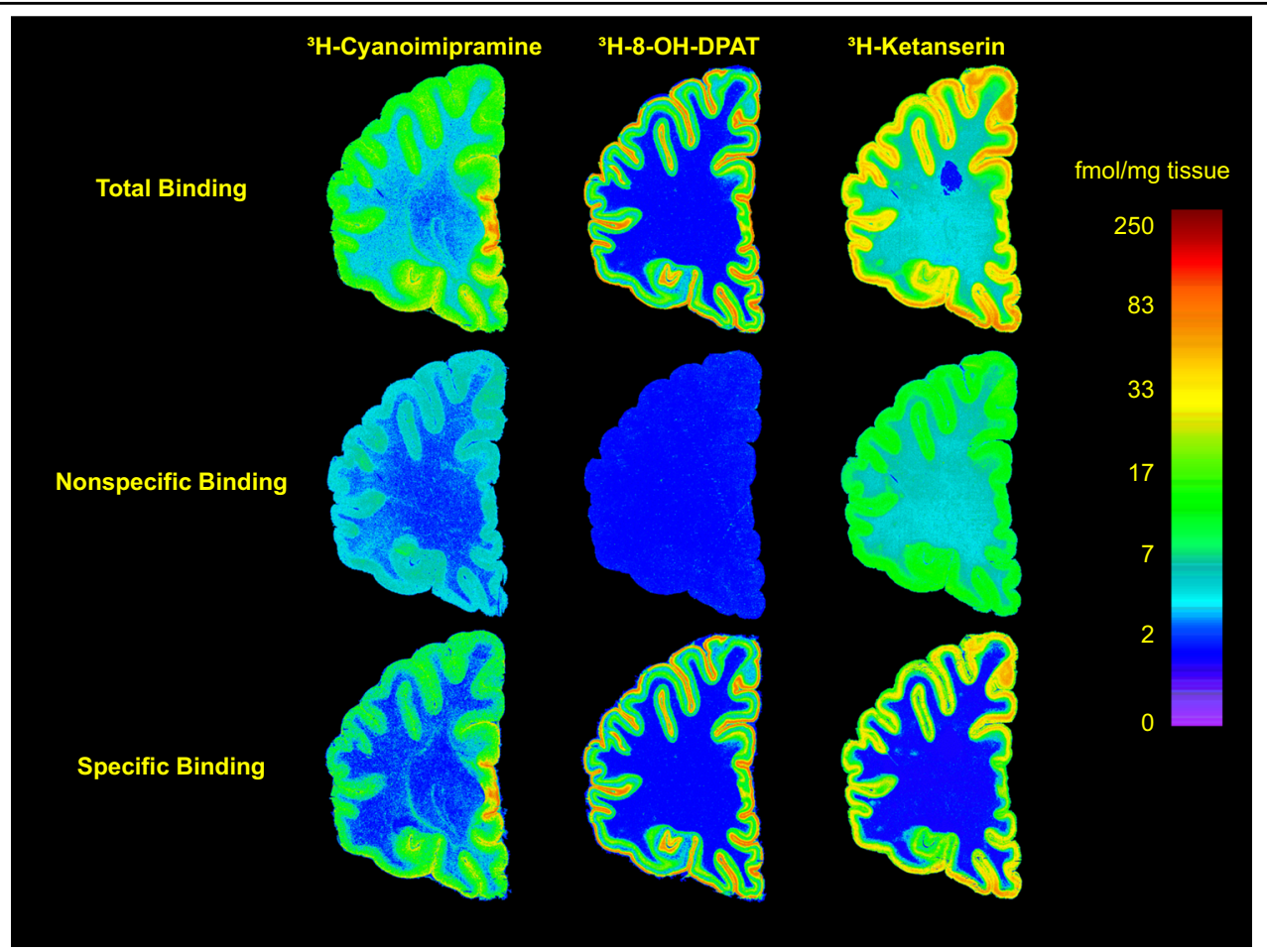

Fig. 1 Representative autoradiograms of receptor binding of $\left[{ }^{3} \mathrm{H}\right]$-Cyanoimipramine to the serotonin transporter (left), $\left[{ }^{3} \mathrm{H}\right]-8-\mathrm{OH}-\mathrm{DPAT}$ to the $5-\mathrm{HT}_{1 \mathrm{~A}}$ receptor (center) and $\left.{ }^{3} \mathrm{H}\right]$-Ketanserin to the $5-\mathrm{HT}_{2 \mathrm{~A}}$ receptor (right). The autoradiograms are from sections cut from the right hemisphere of a representative nonpsychiatric control. The upper row has images of total binding, the middle row is of nonspecific binding and the lower row has subtracted images of specific binding. See methods for displacers and assay conditions. The images were calibrated to fmol/mg tissue using radioactivity standards and color-mapped to a single scale on the right

\section{$2 \mathrm{nM}{ }^{3} \mathrm{H}-$ Ket, $1 \mu \mathrm{M}$ prazosin and $1 \mu \mathrm{M}$} tetrabenazine.

\section{Statistical analyses}

Statistical tests were done using SPSS (Version 24, IBM Analytics, NY) and R (Version 3.3.2, R Foundation for Statistical Computing; https://cran.r-project.org).

There were three primary hypotheses: (1) SERT are reduced in suicides; (2) there are more $5-\mathrm{HT}_{1 \mathrm{~A}}$ receptors in the PFC in suicide; and, (3) there are more $5-\mathrm{HT}_{2 \mathrm{~A}}$ receptors in the PFC in suicides. Linear models were used since the response variables were continuous (scalar) (SPSS Procedures UNIANOVA, REGRESSION, and TTEST). Post hoc tests were performed only when main factors had a significant interaction with brain region. Suicide and MDD were fixed factors, brain regions were assigned as a random factor. All models tested included age and sex as covariates, and when found to be significant, correlation analysis was performed. Statistical tests were performed on raw values. The three receptors (SERT, 5- $\mathrm{HT}_{1 \mathrm{~A}}$ and $5-\mathrm{HT}_{2 \mathrm{~A}}$ ) were examined individually, and while uncorrected $p$-values are reported, a Bonferroni-adjusted significance level of 0.017 was used to preserve an experiment-wise Type I error rate of 0.05 for the primary analyses.

We sought to determine whether any differences in suicide, MDD, AUD or reported early life adversity (ELA) were widespread in PFC or anatomically discrete. The Brodmann areas present at this anatomical level included BA8, BA9, BA46, BA45, BA47, BA11, BA12, BA24, and BA32.

The primary hypotheses were re-tested in a sensitivity analysis limited to subjects with psychological autopsy: Two secondary analyses for each outcome tested whether the difference of binding in suicides is accounted for by the MDD or AUD; a third analysis tested whether binding is associated with aggression or reported early childhood adversity. These hypotheses were made a priori, but being secondary, no $p$-value adjustment was made for multiple testing other than using the 0.017 significance level to adjust for the three outcome measures.

\section{Results}

Serotonin transporter (SERT)

In nonsuicides $(n=143)$, SERT binding ranged from $5.9 \pm 2.1 \mathrm{fmol} / \mathrm{mg}$ tissue in BA8 to $23.9 \pm 12.0 \mathrm{fmol} / \mathrm{mg}$ tissue in BA24 (mean $\pm \mathrm{SD}$, Table 3). 


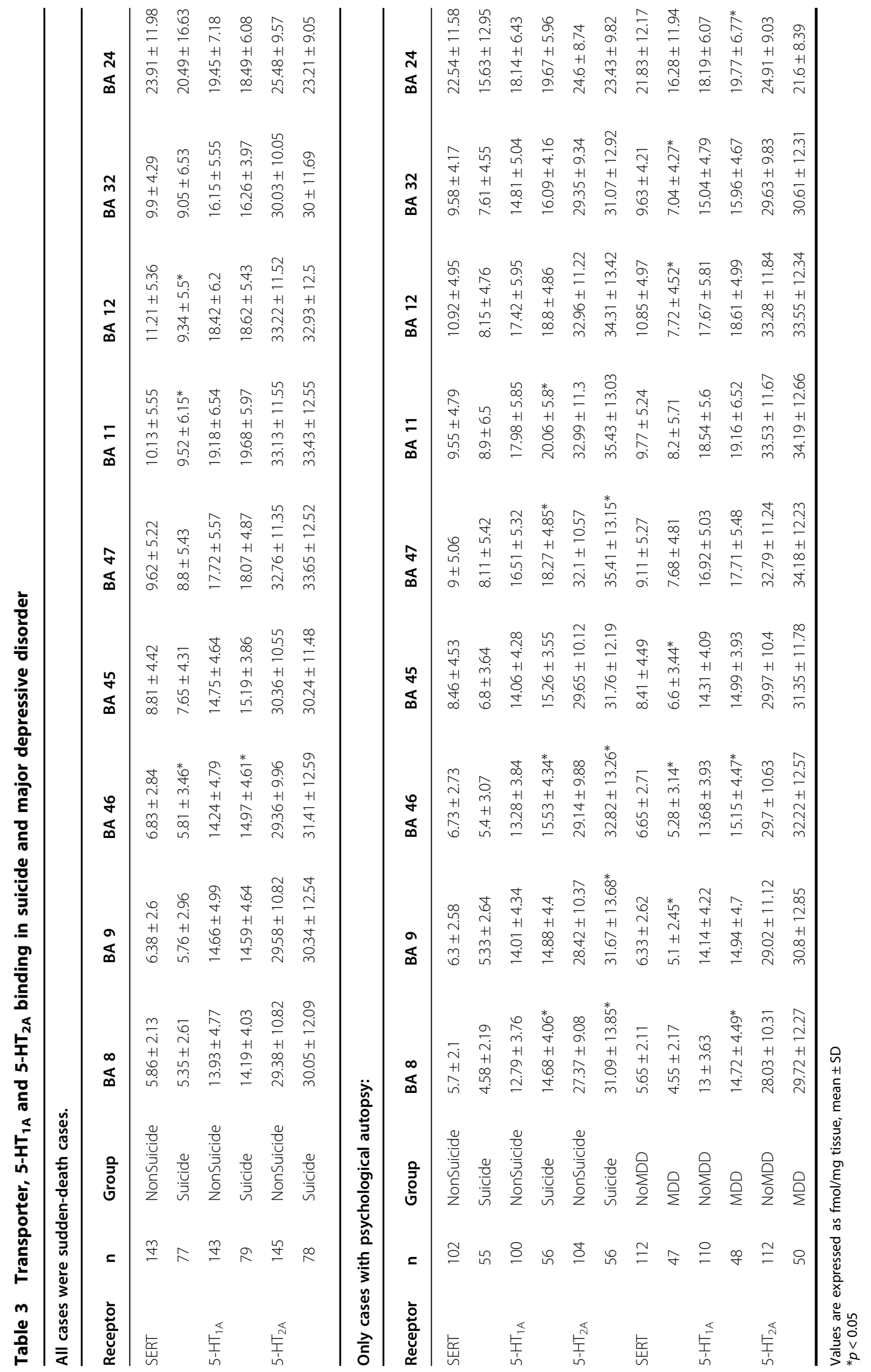




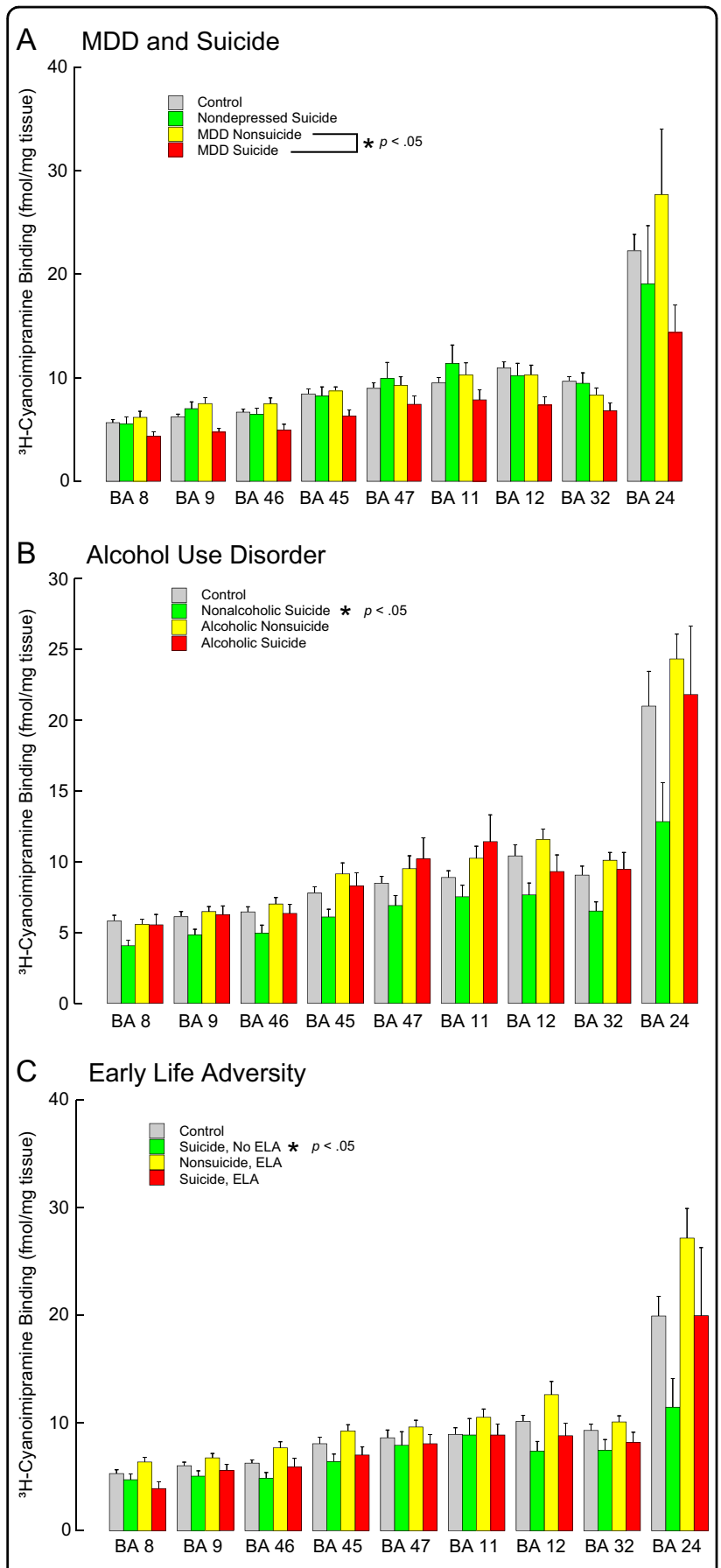

Fig. 2 Serotonin transporter (SERT) binding in the prefrontal cortex. A suicide and major depressive disorder (MDD), B alcohol use disorder and $\mathbf{C}$ early life adversity (ELA). SERT sites were labeled with $\left[{ }^{3} \mathrm{H}\right]$-Cyanoimipramine. Note that: SERT is less in depressed suicide decedents and with MDD. With AUD there is more SERT but only in suicides, and there is more in ELA but only in nonsuicides. Values are expressed as mean \pm SEM

\section{Suicide}

Including all cases, and adjusting for sex and age, SERT binding was lower in suicides $(F=15.367, \mathrm{df}=1,9, p=$
0.004). There was no interaction between suicide and Brodmann area $(F=0.828, \mathrm{df}=8,1665, p=0.578)$ indicating the effect of suicide was comparable in all areas. Limiting the cases to only those with psychological autopsy, the effect of suicide remained significant $(F=$ 11.464, $\mathrm{df}=1,9, p=0.008$, Fig. 2a).

\section{Major depressive disorder}

There was lower SERT binding with MDD $(F=9.476$, $\mathrm{df}=1,13, p=0.009$ ), and the lower binding was found in all brain regions (region by depression interaction $F=$ $0.378, \mathrm{df}=8,8, p=0.878$ ). In the model with suicide and MDD, the effect of suicide was not significant $(F=5.147$, $\mathrm{df}=1,9, p=0.050$ ) suggesting that lower SERT in suicide is attributable, at least in part, to the MDD diagnosis (Table 3, Fig. 2a).

\section{Alcohol use disorder}

There were cases with AUD in both nonsuicides $(n=53$ with AUD) and suicides ( $n=20$ with AUD). The AUD diagnosis was associated with more SERT (Fig. 2b, Table $4 ; \mathrm{F}=8.135, \mathrm{df}=1,16, p=0.012)$; the AUD interaction with brain region was not significant $(\mathrm{F}=0.671, \mathrm{df}=8,10$, $p=0.708$ ) indicating the effect of AUD was comparable in all areas. In the same model, the suicide effect adjusted for AUD was not significant $(\mathrm{F}=2.972, \mathrm{df}=1,10, p=0.117$ ), suggesting the AUD effect is in nonsuicides (Fig. 2b). Similarly, with MDD in the model, the diagnosis of MDD was also no longer significant $(\mathrm{F}=3.418, \mathrm{df}=1,23, p=$ 0.078). This may reflect the lower rate of MDD in the alcoholics in our sample. In nonalcoholics, 34 of 40 suicides had MDD. In alcoholics, 14 of 58 had MDD.

\section{Adversity}

When childhood adversity was included in the model along with suicide, there were no SERT differences related to childhood adversity $(F=1.907, \mathrm{df}=1,9, p=0.20$, Table $5)$. The suicide effect of less SERT binding was significant $(p=0.006)$ and there was a suicide*adversity interaction $(p=0.007)$ with adversity associated with more SERT binding, but only in non-suicides (Fig. 2c). The interaction term with Brodmann area was significant with the difference localized to BA24.

\section{Sex, age, aggression}

Both sex and age were significant in every statistical model examined. Females $(n=49)$ had less SERT binding than males $(n=171, b=-0.33, \mathrm{t}=-4.27, \mathrm{df}=216, p<$ 0.0001 ) in all BA areas, except BA24 (post hoc test, $p=$ $0.069)$. SERT binding declined with age $(\mathrm{t}=-3.04, \mathrm{df}=$ $215, p=0.0027$ ), and the effect was uniform across brain regions (age by BA interaction $p>0.05$ ). SERT positively correlated with aggression in BA9 $(r=0.193, p=0.0220)$, BA46 $(r=0.270, \quad p=0.0020)$, BA45 $(r=0.179, \quad p=$ 


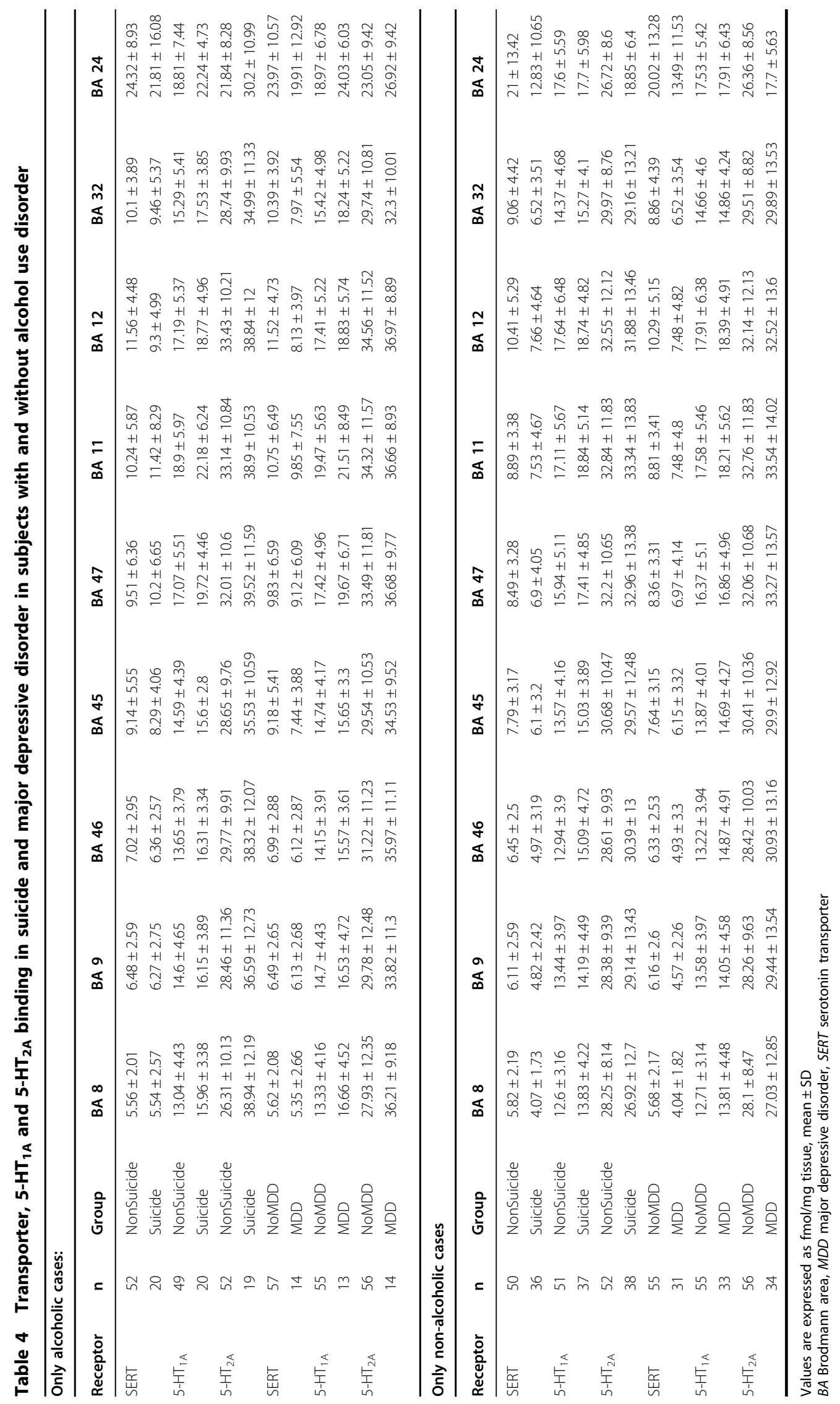




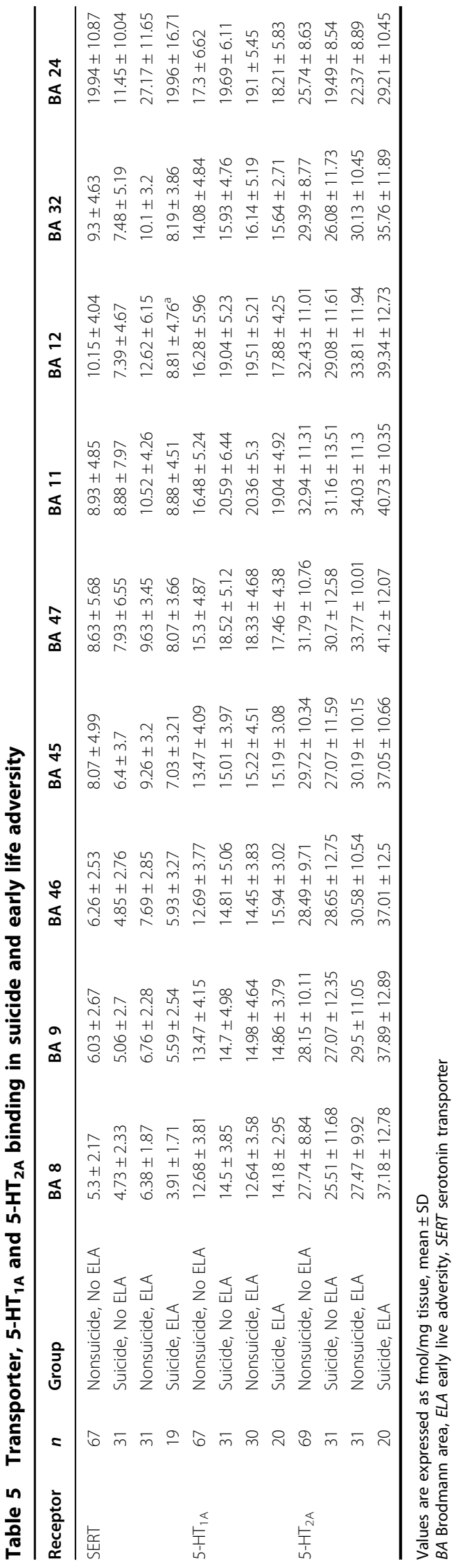

0.0350), BA11 $(\mathrm{r}=0.173, p=0.0460)$ and BA32 $(r=$ $0.198, p=0.022)$ in cases overall.

\section{5- $\mathrm{HT}_{1 \mathrm{~A}}$ receptors}

In nonsuicides $(n=143), 5-\mathrm{HT}_{1 \mathrm{~A}}$ binding ranged from $13.9 \pm 4.8 \mathrm{fmol} / \mathrm{mg}$ tissue in $\mathrm{BA} 8$ to $19.5 \pm 7.2 \mathrm{fmol} / \mathrm{mg}$ tissue in BA24 (Table 3).

\section{Suicide}

There was no significant effect of suicide $(F=0.163$, df $=1,10, p=0.695)$ and the suicide by brain region interaction term was not significant $(F=0.270, \mathrm{df}=8,1714, p$ $=0.976)$. However, in the sensitivity analysis limited to cases with psychological autopsy data, suicide was significant with more $5-\mathrm{HT}_{1 \mathrm{~A}}$ binding $(F=60.049, \mathrm{df}=1,14$, $p<0.001)$ and the suicide by brain region interaction was not significant $(F=0.320, \mathrm{df}=8,1179, p=0.959$, Fig. 3a).

\section{Major depressive disorder}

$5-\mathrm{HT}_{1 \mathrm{~A}}$ binding was not different in $\mathrm{MDD}(\mathrm{F}=2.148$, $\mathrm{df}=1,12, p=0.168)$ and there was no significant interaction between suicide and MDD $(\mathrm{F}=2.680, \mathrm{df}=1,12, p$ $=0.128$ ) or interaction between MDD and Brodmann area $(\mathrm{F}=0.909, \mathrm{df}=8,8, p=0.552$, Table 3, Fig. 3a).

\section{Alcohol use disorder}

With AUD in the model with suicide, MDD and sex, AUD was associated with more $5-\mathrm{HT}_{1 \mathrm{~A}}$ binding $(F=$ $35.703, \mathrm{df}=1,20, p<0.001)$ and the interaction with brain region was not significant $(F=1.852, \mathrm{df}=8,2, p=0.397$, Fig. 3b, Table 4). The effect of suicide was still significant $(F=18.054, \mathrm{df}=1,12, p=0.001)$ and there was a significant interaction between suicide and AUD ( $F=$ 16.562, $\mathrm{df}=1,19, p<0.001$ ) with AUD associated with more $5-\mathrm{HT}_{1 \mathrm{~A}}$ binding but only in suicides. There was no effect of MDD $(p=0.696)$ and there was no interaction between suicide and MDD ( $p=0.087)$, but there was an interaction between MDD and AUD $(F=53.894, \mathrm{df}=$ $1,18, p<0.001$ ) with more $5-\mathrm{HT}_{1 \mathrm{~A}}$ binding only in MDD cases with AUD.

\section{Adversity}

With adversity in the model, suicide was associated with higher $5-\mathrm{HT}_{1 \mathrm{~A}}$ binding $(F=27.697, \mathrm{df}=1,14, p<0.001)$, adversity was not significant $(F=0.619, \mathrm{df}=1,28, p=$ 0.438 , Table 5$)$. There was no interaction between suicide and Brodmann area $(F=0.319, \mathrm{df}=8,8, p=0.937)$. There was an interaction between suicide and adversity $(F=$ $14.133, \mathrm{df}=1,9, p=0.004$ ) with adversity associated with more $5-\mathrm{HT}_{1 \mathrm{~A}}$ binding, but only in non-suicides (Fig. 3c). There was no interaction between adversity and brain region $(F=0.273, \mathrm{df}=8,8, p=0.958)$. 


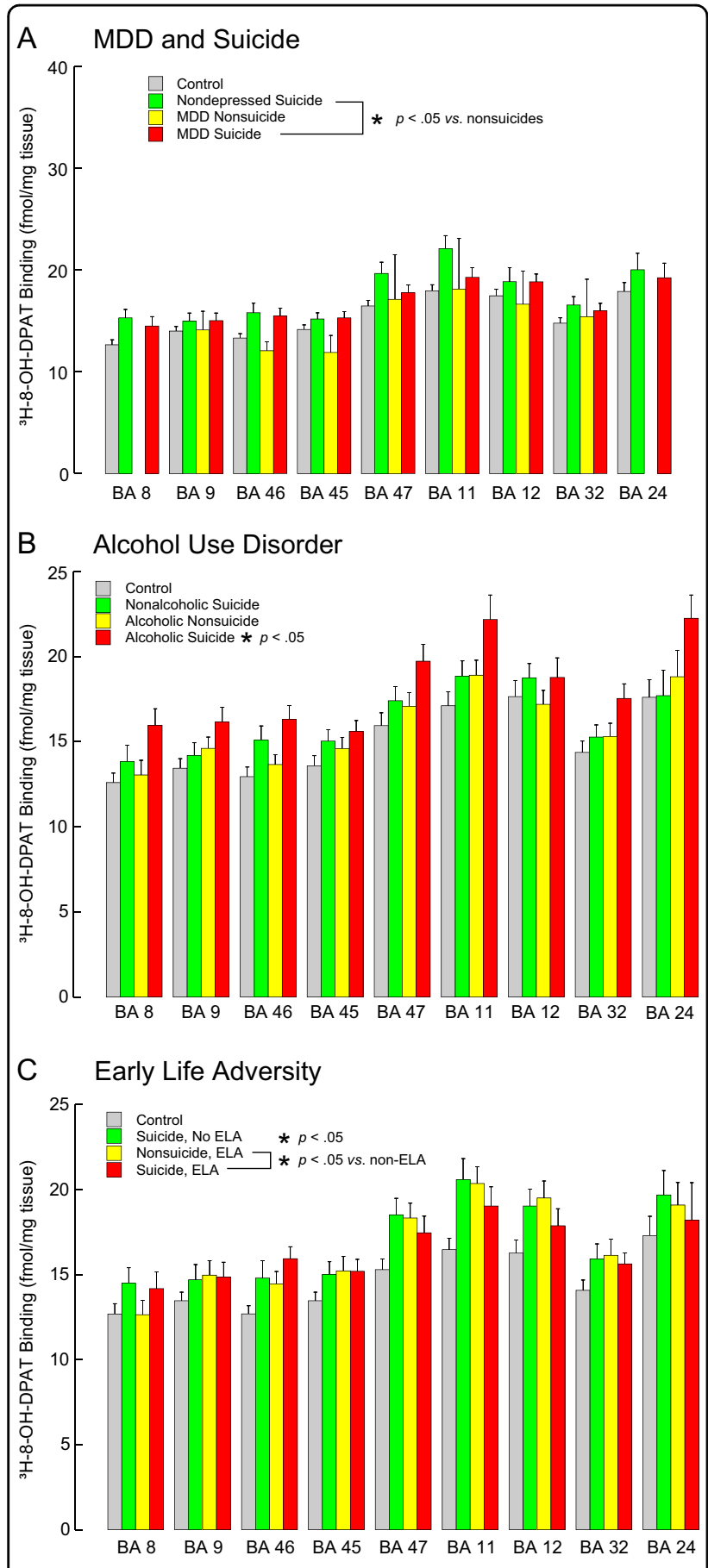

Fig. $35-\mathrm{HT}_{1 \mathrm{~A}}$ receptor binding in the prefrontal cortex. A suicide and major depressive disorder (MDD), $\mathbf{B}$ alcohol use disorder and $\mathbf{C}$ early life adversity (ELA). 5- $\mathrm{HT}_{1 \mathrm{~A}}$ receptors were labeled with $\left.{ }^{3} \mathrm{H}\right]-8$ OH-DPAT. There is no data for BA8 or BA24 for MDD nonsuicides because there was only one case with these regions. Note: $5-\mathrm{HT}_{1 \mathrm{~A}}$ binding was greater in suicides independent of MDD, AUD was associated with higher $5-\mathrm{HT}_{1 \mathrm{~A}}$ binding but only in suicides, and ELA is associated with more $5-\mathrm{HT}_{1 \mathrm{~A}}$ receptor binding. Values are expressed as mean \pm SEM

\section{Sex, age, aggression}

Sex was significant in select models particularly those examining the effect of suicide and AUD. 5- $\mathrm{HT}_{1 \mathrm{~A}}$ binding was negatively correlated with age in BA9, BA46 and BA32 (Pearson correlation values -0.141, -0.147, $-0.151, p$ values $0.037,0.037$ and 0.029 respectively). 5$\mathrm{HT}_{1 \mathrm{~A}}$ binding correlated positively with lifetime aggression in BA9 $(r=.299, p<0.001)$, BA46 $r=.259, p=$ $0.003)$, BA45 $(r=.194, p=0.023)$, BA47 $(r=.258, p=$ $0.002)$, BA11 $(\mathrm{r}=.212, p=0.014)$, BA24 $(r=.248, p=$ $0.036)$ and BA32 $(r=.179, p=0.036)$.

\section{$5-\mathrm{HT}_{2 \mathrm{~A}}$ receptors \\ Suicide}

There was no suicide effect detected overall $(F=2.139$, $\mathrm{df}=1,9, p=0.176)$ and no suicide by region interaction $(F=0.477, \mathrm{df}=8,1687, p=0.873)$. However, in the subgroup with psychological autopsies, there was more 5$\mathrm{HT}_{2 \mathrm{~A}}$ binding in suicides $(F=41.226, \mathrm{df}=1,12, p<0.001$, Table 3$)$. There was no suicide by region interaction $(F=$ 0.386, $\mathrm{df}=8,1193, \quad p=0.929)$ suggesting the greater amount of binding in suicide was widespread and the diagnosis of cases was important (Fig. 4a).

\section{Major depressive disorder}

With MDD in the model, higher $5-\mathrm{HT}_{2 \mathrm{~A}}$ binding was still significant with suicide $(F=18.695, \mathrm{df}=1,30, p<$ 0.001 ) and there was no suicide:Brodmann area interaction $(F=0.510, \mathrm{df}=8,8, p=0.820)$. There was no significant effect of $\operatorname{MDD}(F=2.570, \mathrm{df}=1,39, p=0.117)$ and no MDD by brain region interaction $(F=0.361, \mathrm{df}=$ $8,8, p=0.914)$. This suggests that the diagnosis of MDD does not explain higher $5-\mathrm{HT}_{2 \mathrm{~A}}$ binding in suicides (Fig. $4 a)$.

\section{Alcohol use disorder}

There was no significant association between AUD and $5-\mathrm{HT}_{2 \mathrm{~A}}$ binding $(F=2.302, \mathrm{df}=1,17, p=0.148$, Table 4); there was no interaction between AUD and Brodmann area on binding $(F=0.206, \mathrm{df}=8,1193, p=0.990)$. With AUD in the model with suicide and MDD, the effect of suicide remained and MDD became significant $(F=17.59$, $\mathrm{df}=1,313, \quad p<0.001)$, and there was an interaction between AUD and suicide $(F=31.427, \mathrm{df}=1,130, p<$ 0.001 ) with more $5-\mathrm{HT}_{2 \mathrm{~A}}$ binding in suicides with AUD (Fig. 4b), but not in suicides without AUD. There was no interaction between AUD and $\operatorname{MDD}(F=0.687, \mathrm{df}=1,33$, $p=0.413)$.

\section{Adversity}

Adversity was associated with more $5-\mathrm{HT}_{2 \mathrm{~A}}$ binding $(F$ $=25.484, \mathrm{df}=1,78, \quad p<0.001)$; the brain region by adversity interaction term was not significant $(F=0.743$, $\mathrm{df}=8,8, p=0.658$, Table 5 ). With adversity and suicide in 


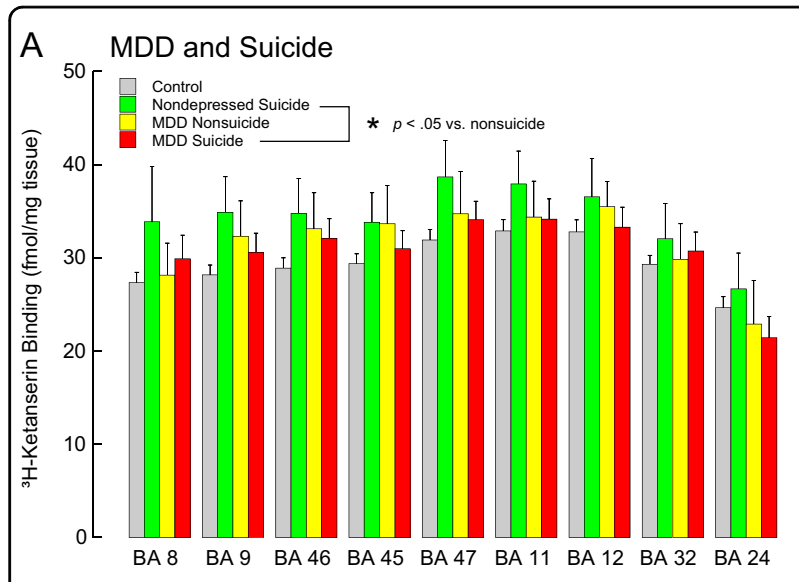

B Alcohol Use Disorder

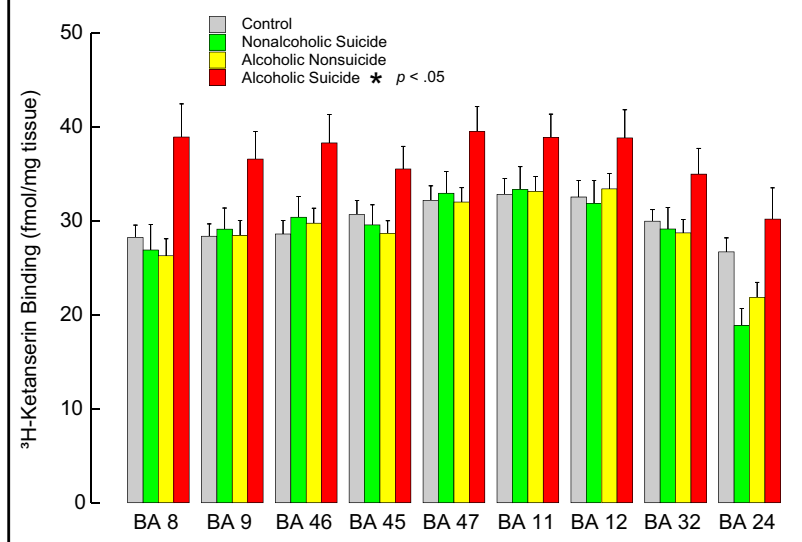

C Early Life Adversity

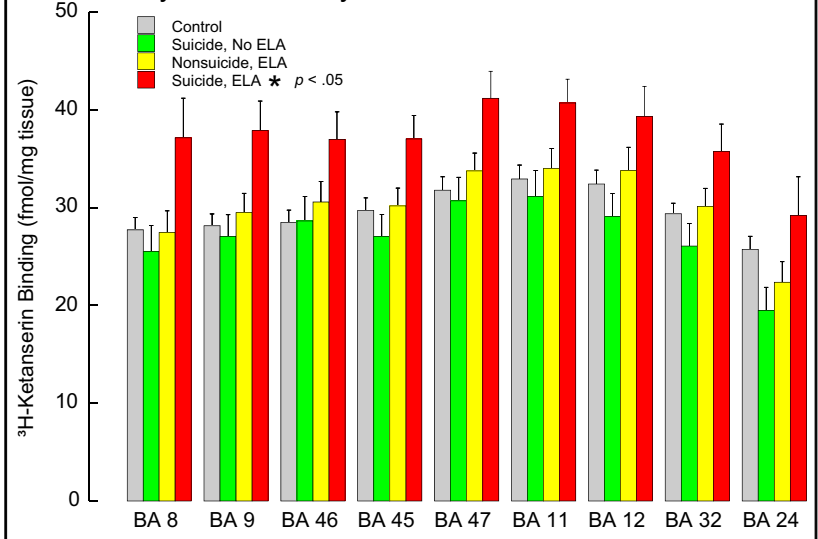

Fig. $45-\mathrm{HT}_{2 \mathrm{~A}}$ receptor binding in the prefrontal cortex. A suicide and major depressive disorder (MDD), B alcohol use disorder and $\mathbf{C}$ early life adversity (ELA). $5-\mathrm{HT}_{2 \mathrm{~A}}$ receptors were labeled with [ $\left.{ }^{3} \mathrm{H}\right]-$ Ketanserin. Note that: there is more $5-\mathrm{HT}_{2 \mathrm{~A}}$ binding in suicides but no difference with MDD; there is more binding in AUD and ELA, but only in suicides. Values are expressed as mean \pm SEM

the model, higher $5-\mathrm{HT}_{2 \mathrm{~A}}$ binding remained associated with suicide $(F=37.658, \mathrm{df}=1,12, p<0.001)$. There was an interaction between suicide and childhood adversity $(F$ $=201.938, \mathrm{df}=1,21, p<0.001)$ such that higher $5-\mathrm{HT}_{2 \mathrm{~A}}$ binding was in suicides with adversity regardless of Brodmann area examined (Fig. 4c).

\section{Sex, age, aggression}

$5-\mathrm{HT}_{2 \mathrm{~A}}$ receptor binding negatively correlated with age in all regions $\left(r=-0.227\right.$ to $-0.441, p=2.43 \times 10^{-9}$ to $\left.7.9 \times 10^{-12}\right)$. Females $(n=48)$ had lower $5-\mathrm{HT}_{2 \mathrm{~A}}$ binding than males $(n=175)(b=-0.14, t=-2.32, \mathrm{df}=218, p=$ 0.0210). $5-\mathrm{HT}_{2 \mathrm{~A}}$ binding correlated positively with aggression in all brain regions $(r=0.270-0.396, p<0.05)$ except BA24 $(r=0.199, p=0.085)$.

\section{Discussion}

The main findings in the present study were: (1) SERT binding was lower in suicides independent of sex, but dependent on MDD diagnosis; higher SERT binding is associated with AUD; (2) $5-\mathrm{HT}_{1 \mathrm{~A}}$ binding was greater in suicides, independent of MDD, while AUD was associated with higher $5-\mathrm{HT}_{1 \mathrm{~A}}$ binding but only in suicides; (3) 5$\mathrm{HT}_{2 \mathrm{~A}}$ binding was greater in suicides only when accounting for the effects of MDD and AUD in the model. (4) Reported childhood adversity was associated with higher SERT, $5-\mathrm{HT}_{1 \mathrm{~A}}$ binding, and $5-\mathrm{HT}_{2 \mathrm{~A}}$ binding. These findings illustrate that the ability to detect differences in SERT, $5-\mathrm{HT}_{1 \mathrm{~A}}$, and $5-\mathrm{HT}_{2 \mathrm{~A}}$ binding in the brain between cases with mood disorders and dying by suicide is dependent on Axis I diagnosis and reported childhood adversity, therein demonstrating the importance of clinical characterization of both cases and controls under investigation. Different findings in alcoholism from depression and suicide indicate distinct serotonin system pathophysiology.

\section{Serotonin transporter}

We previously found lower SERT binding in suicides in ventral $\mathrm{PFC}^{26,27,29}$. We confirm and extend this, finding the lower SERT is widespread and appears associated more with MDD than with suicide. Lower SERT in suicides is reported by some investigators, but not all (see $e^{12,36,37}$ for review). Our current study suggests one factor contributing to the discrepancy between studies is the proportion of MDD cases in the suicide group. Imaging studies in nonfatal attempters also report less SERT ${ }^{22,38-40}$. Interestingly, Miller et al. ${ }^{20}$ reported less SERT in depressed suicide attempters but not depressed nonattempters compared to controls, raising the possibility that SERT is related more to suicidal behavior than to depression. We observed a $p$-value of 0.053 which did not reach statistical significance but arguably is suggestive of an effect of suicide. Our findings here regarding suicide and MDD suggest that low SERT throughout the PFC is related to MDD more than to suicide, and the suicide effect may be the result of a more pronounced difference in the ventral PFC. Hypofunction of the ventral PFC may 
lead to increased suicide risk due to the inability to restrain the self-destructive act.

In AUD, we found more SERT binding, but others report lower SERT in cerebral cortex ${ }^{41}$. No difference in alcoholics or alcoholic-suicides in SERT mRNA was found in BA9 or BA2 $4^{42}$, but there was a negative association between SERT mRNA in BA24 and anxiety symptoms. In in vivo imaging studies, alcoholics had less [11C]McN5652 binding to the SERT ${ }^{43}$. Others ${ }^{44,45}$ did not find any difference in [11C]DASB binding to the SERT in alcoholics. Comorbidity with mood disorders may contribute to the inconsistent findings and future studies of AUD should consider effects of comorbid MDD since the two diagnoses may have opposite effects on binding.

\section{$5-\mathrm{HT}_{1 \mathrm{~A}}$ receptors}

We observed more $5-\mathrm{HT}_{1 \mathrm{~A}}$ binding in suicides, but only in cases that underwent psychological autopsy. We did not detect a difference in $5-\mathrm{HT}_{1 \mathrm{~A}}$ binding in MDD, but we found more $5-\mathrm{HT}_{1 \mathrm{~A}}$ binding associated with AUD. Several investigators, though not all, report higher $5-\mathrm{HT}_{1 \mathrm{~A}}$ binding in depressed suicides (for review see ref. ${ }^{36}$ ). We previously reported ${ }^{26,27}$ higher ${ }^{3} \mathrm{H}-8-\mathrm{OH}-\mathrm{DPAT}$ binding in suicide that was anatomically restricted to ventrolateral prefrontal cortex, as were the increases reported by oth$\mathrm{ers}^{46,47}$. Parsey et al. ${ }^{48}$ found that MDD patients whose depression did not remit had higher $5-\mathrm{HT}_{1 \mathrm{~A}}$ binding and also an over-representation of GG genotype, suggesting that genotype may also affect the level of receptor binding, symptom progression and treatment response. Negative reports did not examine binding in anatomically discrete areas or did not examine ventral prefrontal cortex ${ }^{49-52}$. The lack of agreement about elevated $5-\mathrm{HT}_{1 \mathrm{~A}}$ binding raises the possibility that the differences associated with suicide are anatomically discrete. The radioligand used may also affect receptor binding since antagonist but not agonist binding is decreased in MDD, suggesting binding differences may reflect the G-protein coupled or uncoupled state of the receptor ${ }^{53}$. Lower $5-\mathrm{HT}_{1 \mathrm{~A}}$ receptor binding is reported in the cerebral cortex in alcoholics ${ }^{4,49,54}$. Lastly, we did not find differences in $5-\mathrm{HT}_{1 \mathrm{~A}}$ binding when all cases and controls were examined together, greater $5-\mathrm{HT}_{1 \mathrm{~A}}$ binding in suicides was only found when restricting the analysis to only those cases diagnosed by psychological autopsy. We believe this demonstrates how cases without psychological autopsy can bias, obscure or otherwise influence the outcome of an analysis to the point of affecting the conclusion reached.

In vivo $\mathrm{PET}$ imaging studies report higher $5-\mathrm{HT}_{1 \mathrm{~A}}$ binding in depressed MDD subjects and remitted MDD; ${ }^{55}$ others find less binding ${ }^{56-58}$. The different results may be due to the method of estimating binding ${ }^{55}$. We observed more $5-\mathrm{HT}_{1 \mathrm{~A}}$ binding associated with childhood adversity in nonsuicides, and a rodent study of stress in infants finds increased gene expression ${ }^{59}$.

We find more $5-\mathrm{HT}_{1 \mathrm{~A}}$ binding with AUD, as did Thompson et al. ${ }^{42}$ who found higher $5-\mathrm{HT}_{1 \mathrm{~A}}$ mRNA in BA9 in AUD but not AUD-suicides and not in BA24. Martinez and colleagues did not find any differences in 5$\mathrm{HT}_{1 \mathrm{~A}}$ density in humans with alcohol dependence ${ }^{45}$. Taken together, the findings suggest brain region is important as is the potential for the presence of alcohol status to obscure effects of suicide. Genomic studies may be helpful for understanding $5 \mathrm{HT}_{1 \mathrm{~A}}$ regulation in suicide, MDD and AUD.

\section{5- $\mathrm{HT}_{2 \mathrm{~A}}$ receptors}

We found higher $5-\mathrm{HT}_{2 \mathrm{~A}}$ binding in suicide, but only in cases with psychological autopsy. Other studies report higher $^{28,60,61}$, lower ${ }^{62}$ and no difference ${ }^{52}$ in $5-\mathrm{HT}_{2 \mathrm{~A}}$ binding in suicide. Both higher and lower binding are also reported in MDD in vivo (see ref. ${ }^{15}$ for review). We detected more $5-\mathrm{HT}_{2 \mathrm{~A}}$ binding in AUD in the present study but not previously ${ }^{31}$. No difference in $5-\mathrm{HT}_{2 \mathrm{~A}}$ binding was reported in AUD by others ${ }^{63}$. Most studies did not separate effects of depression or alcoholism from suicide. Therefore, we extend previous observations by finding that $5-\mathrm{HT}_{2 \mathrm{~A}}$ binding is greater in suicide alcoholics and in suicides with ELA but is not increased with MDD. Another possible explanation for the discrepancies is the use of an agonist versus antagonist ligand; higher binding in suicide was detected using the agonist LSD ${ }^{28,64}$, while the antagonist Ketanserin detected lower or no change in suicide. Another possible explanation for the discrepancy is the ligand specificity. It is known that ketanserin has affinity for tetrabenazine receptors, alpha ${ }_{1}$ adrenergic receptors and histamine receptors. We blocked for these receptors during the incubations. Some of the findings in the literature, including our own, were

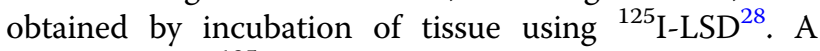
problem with ${ }^{125}$ I-labeled ligands is that differences in tissue thickness result in a darker image and higher measured receptor density. While this may pose less of a problem for small pieces of tissue, when sectioning entire hemispheres, inevitably there will be parts of the tissue that are thicker producing a darker image. We found a positive correlation between $5-\mathrm{HT}_{2 \mathrm{~A}}$ binding and aggression raising the possibility that increased $5-\mathrm{HT}_{2 \mathrm{~A}}$ binding in suicide is associated with the increased aggression commonly associated with suicide behavior ${ }^{30}$. Alternatively, the discrepant findings may be due to childhood adversity exposure. This not only implies a relationship between the $5-\mathrm{HT}_{2 \mathrm{~A}}$ receptor and brain development and/or the development of AUD, but also demonstrates the importance of the diagnostic composition of the sample under study. 


\section{Early life adversity (ELA)}

We found that reported ELA was associated with more SERT, 5- $\mathrm{HT}_{1 \mathrm{~A}}$ and $5-\mathrm{HT}_{2 \mathrm{~A}}$ receptor binding. Reported ELA was associated with lower SERT in vivo in MDD ${ }^{65}$. Childhood adversity was not associated with $5-\mathrm{HT}_{1 \mathrm{~A}}$ receptor density ${ }^{16}$, and early maternal separation, an animal model of childhood adversity in humans, was not associated with difference in $5-\mathrm{HT}_{1 \mathrm{~A}}$ mRNA gene expression in rats $^{66}$. In peer-reared rhesus monkeys, another animal model of childhood adversity, $5-\mathrm{HT}_{1 \mathrm{~A}}$ receptor binding was less in father-reared compared with mother-reared animals, but greater in peer-reared females ${ }^{67}$.

Gene-environment interactions are increasingly found between early life stress and risk for psychiatric illness, including MDD (see ref. ${ }^{68}$ for review) and suicide risk (see ref. ${ }^{69}$ ). An interaction is widely reported between lower expressing alleles of the SERT gene promotor variant (5-HTTLPR), stressful early life events and increased risk for $\mathrm{MDD}^{70,71}$ and suicide ${ }^{72}$. Interestingly, it has been found that the $S$ allele and the early adversity effects can be additive suggesting persistent changes in SERT expression may relate to altered serotonergic neurotransmission levels which could bring about increased disease risk $^{73}$. No gene-environment interaction is reported between the $5-\mathrm{HT}_{1 \mathrm{~A}}{ }^{74}$ or $5-\mathrm{HT}_{2 \mathrm{~A}}{ }^{75}$ receptor gene polymorphisms and MDD and childhood stress. Alternatively, innate receptor binding level may mitigate the effects of gene $x$ environment interactions.

\section{Sex}

We found females have less SERT and $5-\mathrm{HT}_{2 \mathrm{~A}}$ binding than males. In contrast, sex was not a significant determinant in most of the models in which we examined the $5-\mathrm{HT}_{1 \mathrm{~A}}$ receptor. Males and females differ in their prevalence in psychiatric illnesses (see refs. ${ }^{68,76-78}$ ) and in serotonergic receptor densities ${ }^{79,80}$. We previously reported sex differences in SERT and $5-\mathrm{HT}_{1 \mathrm{~A}}{ }^{26}$. In vivo receptor binding studies as measured by PET, report that women have more $5-\mathrm{HT}_{1 \mathrm{~A}}$ receptors ${ }^{81}$ and fewer SERT ${ }^{80}$ and $5-\mathrm{HT}_{2 \mathrm{~A}}$ receptors ${ }^{82}$ compared with men. Others do not find sex differences ${ }^{49,83,84}$.

\section{Conclusions}

Reduced serotonergic neurotransmission has been a long-standing hypothesis in the etiology of suicide and mood disorders. The SERT is located on axons and axon terminals and are an indication of serotonergic innervation and intrasynaptic serotonin levels ${ }^{85}$. Less SERT in depressed suicides therefore suggests less innervation or greater SERT internalization secondary to less intrasynaptic 5 - HT. $5-\mathrm{HT}_{1 \mathrm{~A}}$ and $5-\mathrm{HT}_{2 \mathrm{~A}}$ receptors in the PFC are located predominantly on cortical interneurons. We previously reported more $5-\mathrm{HT}_{1 \mathrm{~A}}$ and $5-\mathrm{HT}_{2 \mathrm{~A}}$ receptor binding in the PFC of depressed suicides, but only when we corrected for the density of cortical interneurons ${ }^{86} .5-$ $\mathrm{HT}_{1 \mathrm{~A}}$ receptor activation results in hyperpolarization and a decrease in neuronal activity in $\mathrm{PFC}^{87}$ on pyramidal neurons and cortical interneurons.

The causes of receptor differences in suicide is unclear. Evidence for receptor up- and down- regulation comes from several sources. Serotonin receptor down regulation has long been suggested as a mechanism of action for antidepressant drugs (see refs. ${ }^{88-90}$ ). By the converse, in classic theories of receptor regulation, reduced 5-HT agonism or long term receptor blockade may lead to upregulation of postsynaptic receptors, but the mechanisms of receptor regulation are complicated, differ by receptor and even by brain region for the same receptor and are not addressed in the current study (for reviews see refs. ${ }^{90-94}$ ).

An increase in $5-\mathrm{HT}_{1 \mathrm{~A}}$ receptors in PFC suggests an inhibition of excitatory output from cortical regions that mediate executive function and behavioral restraint. We hypothesize that reduced cortical activity may be a topdown cause of a reduction in restraint and increase in the risk for suicide behavior. Cognitive testing has been used to find that suicide attempters have worse inhibitory control in executive functioning skills; ${ }^{95}$ see ref. ${ }^{96}$ for review). Neuroimaging studies of brain structure report prefrontal deficits in suicide behavior including impaired decision making and social assessment ${ }^{97,98}$. We now report altered 5-HT receptors in the same prefrontal cortex regions. Multimodal imaging studies of structure and connectivity in suicide attempters ${ }^{1}$, such as those used in connectomic studies ${ }^{99,100}$, support this model.

\section{Strengths and limitations}

In the present study we could compare effects across brain regions related to MDD, suicide, AUD, and childhood adversity and consider the impact of age and sex because we were able to draw upon the largest known collection of human postmortem cases with quantitative receptor autoradiography and psychological autopsy data. Our findings demonstrate the importance of clinical characterization of all cases, including the "controls". We and others have shown how lack of reproducible findings in postmortem studies of suicide can be attributed to effects of antemortem factors, PMI, toxicology, neuropathology, clinical diagnosis, brain region identification and even freezer storage time ${ }^{13,101-103}$. The larger group size studied here, not only provided more statistical power for detecting differences, it accounted for potential receptor binding effects associated with comorbid diagnoses by using psychological autopsy to identify the presence of any comorbid illnesses and then including the diagnosis in the statistical model of the outcome measure. Effects detected in the sensitivity analysis, that were not 
detected in the analysis of the larger sample, which included cases that had not undergone psychological autopsy, further illustrates that undetected diagnoses can introduce bias in results that can obscure detection of differences between groups. The inclusion of alcoholics and subjects with other comorbid diagnoses provided the opportunity to begin to understand how additional illness burden can change the associated brain receptors, but a more clinically homogeneous sample increased the detectability of receptor differences. Regardless of the reliability and validity of the psychological autopsy procedure, it is not infallible, and the possibility remains that there are cases, for example suffering from an MDD episode at the time of death, that were not diagnosed or detected whether or not the psychological autopsy was performed, and these types of cases could affect the outcome. Postmortem studies have the inherent limitation of being cross-sectional and cannot address cause and effect relationships. Another limitation is not knowing the cellular sources giving rise to the receptors being measured as is coming through laser capture microdissection and cellular fractionation. Receptor binding is an endpoint measure and does nothing to address whether differences reflect changes in transcription, translation or posttranslational modification. Likewise, receptor expression is under genetic and epigenetic control and none of this is examined here, nor can it be.

Future work should examine SERT, $5 \mathrm{HT}_{1 \mathrm{~A}}$, and $5 \mathrm{HT}_{2 \mathrm{~A}}$ binding in nonfatal suicide attempts in mood disorders and other diagnoses, and consider the effects of reported childhood adversity to determine the extent that any differences are part of these diagnostic entities or the diathesis for suicidal behavior. Indeed, there are several reports in the literature examining clinical similarities and differences between suicide attempters and completers ${ }^{104-106}$, and neurochemical similarities and differences $^{107-109}$. The presence of differences in attempters to completers will suggest the differences are not only present antemortem, but will also be informative as to whether there is a continuum of differences in the brain in suicide and completers represent the most extreme form of the behavior. Future potential therapeutic approaches to the prevention of suicide, the treatment of MDD or AUD and reversing effects of childhood adversity, could then be developed to target these molecules.

\footnotetext{
Acknowledgements

We are grateful to Virginia L. Johnson (autoradiography analysis) and Manuela Douglas (brain sectioning and staining) for their technical expertise. This work was supported by grants from the National Institute of Mental Health and the National Institute on Alcohol Abuse and Alcoholism (MH40210, AA09004, MH62185 and AA11293) and the Diane Goldberg Foundation. Some of the brain samples and their psychiatric characterization and storage were funded by $\mathrm{NIH}$ grants $\mathrm{MH} 90964$ and $\mathrm{MH} 64168$.
}

\section{Author details}

${ }^{1}$ Department of Psychiatry, Columbia University College of Physicians and Surgeons, New York, NY, USA. ${ }^{2}$ Division of Molecular Imaging and Neuropathology, Columbia University and New York State Psychiatric Institute, New York, NY, USA. ${ }^{3}$ Division of Biostatistics, Columbia University and New York State Psychiatric Institute, New York, NY, USA. ${ }^{4}$ Department of Pathology and Cell Biology, Columbia University College of Physicians and Surgeons, New York, NY, USA. ${ }^{5}$ Macedonian Academy of Sciences and Arts, Skopje, Macedonia

\section{Conflict of interest}

J.M. receives royalties for the commercial use of the C-SSRS from the Research Foundation for Mental Hygiene. V.A., M.D.U. A.J.D. S.A.K., M.J.B. declare that they have no conflict of interest.

\section{Publisher's note}

Springer Nature remains neutral with regard to jurisdictional claims in published maps and institutional affiliations.

Supplementary Information accompanies this paper at (https://doi.org/ 10.1038/s41398-018-0309-1).

Received: 26 July 2018 Accepted: 5 August 2018

Published online: 14 December 2018

\section{References}

1. van Heeringen, K. \& Mann, J. J. The neurobiology of suicide. Lancet Psychiatry 1, 63-72 (2014)

2. Mann, J. J. \& Arango, V. Suicide: An Unnecessary Death. 2nd edn., (Oxford, Oxford OX2 6DP, United Kingdom, 2015).

3. LeMarquand, D., Pihl, R. O. \& Benkelfat, C. Serotonin and alcohol intake, abuse, and dependence: clinical evidence. Biol. Psychiatry 36, 326-337 (1994).

4. Underwood, M. D., Mann, J. J. \& Arango, V. Serotonergic and noradrenergic neurobiology of alcoholic suicide. Alcohol. Clin. Exp. Res. 28, 57s-69s (2004)

5. Pompili, M. et al. Suicidal behavior and alcohol abuse. Int. J. Environ. Res. Public Health 7, 1392-1431 (2010).

6. Becker, A., Ehret, A. M. \& Kirsch, P. From the neurobiological basis of comorbid alcohol dependence and depression to psychological treatment strategies: study protocol of a randomized controlled trial. BMC Psychiatry 17, 153 (2017).

7. Johnson, J. G. et al. Childhood adversities, interpersonal difficulties, and risk for suicide attempts during late adolescence and early adulthood. Arch. Gen. Psychiatry 59, 741-749 (2002).

8. Enns, M. W. et al. Childhood adversities and risk for suicidal ideation and attempts: a longitudinal population-based study. Psychol. Med. 36, 1769-1778 (2006).

9. Caspi, A. et al. Influence of life stress on depression: moderation by a polymorphism in the 5-HTT gene. Science 301, 386-389 (2003).

10. Labonte, B., Turecki, G. in The Neurobiological Basis of Suicide (ed Dwivedi, Y.) 275-296 (CRC Press, Boca Raton, 2012).

11. Yang, B. Z. et al. Child abuse and epigenetic mechanisms of disease risk. Am. J. Prev. Med. 44, 101-107 (2013).

12. Furczyk, K., Schutová, B., Michel, T. M., Thome, J. \& Büttner, A. The neurobiology of suicide - A review of post-mortem studies. J. Mol. Psychiatry 1, 2 (2013).

13. Lewis, D. A. The human brain revisited. Opportunities and challenges in postmortem studies of psychiatric disorders. Neuropsychopharmacology. 26, 143-154 (2002).

14. Prabhakaran, J. et al. Synthesis, in vitro and in vivo evaluation of [11C]MMTP: a potential PET ligand for mGluR1 receptors. Bioorg. Med. Chem. Lett. 20, 3499-3501 (2010).

15. Savitz, J. B. \& Drevets, W. C. Neuroreceptor imaging in depression. Neurobiol. Dis. 52, 49-65 (2013)

16. Sullivan, G. M. et al. Positron emission tomography quantification of serotonin(1A) receptor binding in suicide attempters with major depressive disorder. JAMA Psychiatry 72, 169-178 (2015).

17. Meyer, J. H. et al. Prefrontal cortex 5-HT2 receptors in depression: an [18F] setoperone PET imaging study. Am. J. Psychiatry 156, 1029-1034 (1999). 
18. Audenaert, K., Peremans, K., Goethals, I. \& van Heeringen, C. Functional imaging, serotonin and the suicidal brain. Acta Neurol. Belg. 106, 125-131 (2006).

19. Parsey, R. V. et al. Lower serotonin transporter binding potential in the human brain during major depressive episodes. Am. J. Psychiatry 163, 52-58 (2006).

20. Miller, J. M. et al. Positron emission tomography quantification of serotonin transporter in suicide attempters with major depressive disorder. Biol. Psychiatry 74, 287-295 (2013).

21. Yeh, Y. W. et al. Incongruent reduction of serotonin transporter associated with suicide attempts in patients with major depressive disorder: a positron emission tomography study with 4-[18F]-ADAM. Int. J. Neuropsychopharmacol. 18, pyu065 (2014).

22. Oquendo, M. A. et al. Positron emission tomographic imaging of the serotonergic system and prediction of risk and lethality of future suicidal behavior. JAMA Psychiatry 73, 1048-1055 (2016).

23. Malone, K. M., Corbitt, E. M., Li, S. \& Mann, J. J. Prolactin response to fenfluramine and suicide attempt lethality in major depression. Br. J. Psychiatry 168, 324-329 (1996).

24. Mann, J. J. \& Malone, K. M. Cerebrospinal fluid amines and higher-lethality suicide attempts in depressed inpatients. Biol. Psychiatry 41, 162-171 (1997)

25. Oquendo, M. A. et al. Positron emission tomography of regional brain metabolic responses to a serotonergic challenge and lethality of suicide attempts in major depression. Arch. Gen. Psychiatry 60, 14-22 (2003).

26. Arango, V., Underwood, M. D., Gubbi, A. V. \& Mann, J. J. Localized alterations in pre- and postsynaptic serotonin binding sites in the ventrolateral prefrontal cortex of suicide victims. Brain Res. 688, 121-133 (1995).

27. Underwood, M. D. et al. Neuron density and serotonin receptor binding in prefrontal cortex in suicide. Int. J. Neuropsychopharmacol. 15, 435-447 (2012).

28. Arango, V. et al. Autoradiographic Demonstration of Increased Serotonin 5HT2 and Beta-Adrenergic-Receptor Binding-Sites in the Brain of Suicide Victims. Arch. Gen. Psychiatry 47, 1038-1047 (1990).

29. Mann, J. J. et al. A serotonin transporter gene promoter polymorphism (5HTTLPR) and prefrontal cortical binding in major depression and suicide. Arch. Gen. Psychiatry 57, 729-738 (2000).

30. Oquendo, M. A. et al. Higher postmortem prefrontal 5-HT2A receptor binding correlates with lifetime aggression in suicide. Biol. Psychiatry $\mathbf{5 9}$ 235-243 (2006).

31. Underwood, M. D., Mann, J. J., Huang, Y. Y. \& Arango, V. Family history of alcoholism is associated with lower 5-HT2A receptor binding in the prefrontal cortex. Alcohol. Clin. Exp. Res. 32, 593-599 (2008).

32. Kelly, T. M. \& Mann, J. J. Validity of DSM-III-R diagnosis by psychological autopsy: a comparison with clinician ante-mortem diagnosis. Acta Psychiatr. Scand. 94, 337-343 (1996).

33. Spitzer, R. L., Williams, J. B. W., Gibbon, M. \& First, M. B. Instruction Manual for the Structured Clinical Interview for DSM-III-R (SCID, 5/1/89 Revision). (Biometrics Research Department, New York State Psychiatric Institute: New York, 1989).

34. Brown, G. L., Goodwin, F. K., Ballenger, J. C., Goyer, P. F. \& Major, L. F. Aggression in humans correlates with cerebrospinal fluid amine metabolites. Psychiatry Res. 1, 131-139 (1979).

35. Hoyer, D., Pazos, A., Probst, A. \& Palacios, J. M. Serotonin receptors in the human brain. I. Characterization and autoradiographic localization of $5-H_{1} A$ recognition sites. Apparent absence of $5-\mathrm{HT}_{1 \mathrm{~B}}$ recognition sites. Brain Res. 376, 85-96 (1986).

36. Arango, V. \& Mann, J. J. in Neurobiology of Mental Illness, 3rd edn (eds Charney, D. \& Nestler E. J) 515-529 (Oxford University Press: Oxford, UK, 2009).

37. Stockmeier, C. A. Involvement of serotonin in depression: evidence from postmortem and imaging studies of serotonin receptors and the serotonin transporter. J. Psychiatr. Res. 37, 357-373 (2003).

38. Parsey, R. V. et al. Acute occupancy of brain serotonin transporter by sertraline as measured by [C-11]DASB and positron emission tomography. Biol. Psychiatry 59, 821-828 (2006).

39. Parsey, R. V. et al. Metabolite considerations in the in vivo quantification of serotonin transporters using 11C-DASB and PET in humans. J. Nucl. Med. 47 1796-1802 (2006).

40. Cannon, D. M. et al. Elevated serotonin transporter binding in major depressive disorder assessed using positron emission tomography and [11C] DASB; comparison with bipolar disorder. Biol. Psychiatry 62, 870-877 (2007)

41. Mantere, T. et al. Serotonin transporter distribution and density in the cerebral cortex of alcoholic and nonalcoholic comparison subjects: a whole- hemisphere autoradiography study. Am. J. Psychiatry 159, 599-606 (2002).

42. Thompson, P. M., Cruz, D. A., Olukotun, D. Y. \& Delgado, P. L. Serotonin receptor, SERT mRNA and correlations with symptoms in males with alcohol dependence and suicide. Acta Psychiatr. Scand. 126, 165-174 (2012).

43. Szabo, Z. et al. Positron emission tomography imaging of the serotonin transporter in subjects with a history of alcoholism. Biol. Psychiatry 55, 766-771 (2004).

44. Brown, A. K. et al. PET [11C]DASB imaging of serotonin transporters in patients with alcoholism. Alcohol.: Clin. Exp. Res. 31, 28-32 (2007).

45. Martinez, D. et al. Positron emission tomography imaging of the serotonin transporter and 5-HT(1A) receptor in alcohol dependence. Biol. Psychiatry 65, 175-180 (2009).

46. Matsubara, S., Arora, R. C. \& Meltzer, H. Y. Serotonergic measures in suicide brain: 5-HT1A binding sites in frontal cortex of suicide victims. J. Neural Transm. Gen. Sect. 85, 181-194 (1991).

47. Joyce, J. N. et al. Serotonin uptake sites and serotonin receptors are altered in the limbic system of schizophrenics. Neuropsychopharmacology 8, 315-336 (1993).

48. Parsey, R. V. et al. Higher 5-HT(1A) receptor binding potential during a major depressive episode predicts poor treatment response: preliminary data from a naturalistic study. Neuropsychopharmacology 31, 1745-1749 (2006).

49. Dillon, K. A., Gross-Isseroff, R., Israeli, M. \& Biegon, A. Autoradiographic analysis of serotonin $5-\mathrm{HT}_{1 \mathrm{~A}}$ receptor binding in the human brain postmortem: effects of age and alcohol. Brain Res. 554, 56-64 (1991).

50. Arranz, B., Eriksson, A., Mellerup, E., Plenge, P. \& Marcusson, J. Brain 5-HT1A, 5HT1D, and 5-HT2 receptors in suicide victims. Biol. Psychiatry 35, 457-463 (1994).

51. Lowther, S. et al. 5-HT1A receptor binding sites in post-mortem brain samples from depressed suicides and controls. J. Affect Disord. 42, 199-207 (1997).

52. Stockmeier, C. A. et al. Serotonin receptors in suicide victims with major depression. Neuropsychopharmacology 16, 162-173 (1997).

53. Stockmeier, C. A. et al. Antagonist but not agonist labeling of serotonin-1A receptors is decreased in major depressive disorder. J. Psychiatr. Res. $\mathbf{4 3}$ 887-894 (2009).

54. Storvik, M., Hakkinen, M., Tupala, E. \& Tiihonen, J. 5-HT(1A) receptors in the frontal cortical brain areas in Cloninger type 1 and 2 alcoholics measured by whole-hemisphere autoradiography. Alcohol. Alcohol. 44, 2-7 (2009).

55. Parsey, R. V. et al. Higher serotonin $1 \mathrm{~A}$ binding in a second major depression cohort: modeling and reference region considerations. Biol. Psychiatry 68, 170-178 (2010).

56. Hirvonen, J. et al. Decreased brain serotonin 5-HT1A receptor availability in medication-naive patients with major depressive disorder: an in-vivo imaging study using PET and [carbonyl-11C]WAY-100635. Int. J. Neuropsychopharmacol. 11, 465-476 (2008).

57. Drevets, W. C. et al. PET imaging of serotonin $1 \mathrm{~A}$ receptor binding in depression. Biol. Psychiatry 46, 1375-1387 (1999).

58. Sargent, P. A. et al. Brain serotonin 1A receptor binding measured by positron emission tomography with [11C]WAY-100635: effects of depression and antidepressant treatment. Arch. Gen. Psychiatry 57, 174-180 (2000).

59. Le Francois, B. et al. Chronic mild stress and antidepressant treatment alter 5HT1A receptor expression by modifying DNA methylation of a conserved Sp4 site. Neurobiol. Dis. 82, 332-341 (2015).

60. Turecki, G. et al. Prediction of level of serotonin $2 \mathrm{~A}$ receptor binding by serotonin receptor $2 \mathrm{~A}$ genetic variation in postmortem brain samples from subjects who did or did not commit suicide. Am. J. Psychiatry 156, 1456-1458 (1999).

61. Pandey, G. N. et al. Higher expression of serotonin $5-H T(2 A)$ receptors in the postmortem brains of teenage suicide victims. Am. J. Psychiatry 159, 419-429 (2002).

62. Gross-Isseroff, R., Salama, D., Israeli, M. \& Biegon, A. Autoradiographic analysis of $\left[{ }^{3} \mathrm{H}\right]$ ketanserin binding in the human brain postmortem: effect of suicide. Brain Res. 507, 208-215 (1990).

63. Erritzoe, D. et al. Brain serotonin $2 \mathrm{~A}$ receptor binding: relations to body mass index, tobacco and alcohol use. Neuroimage 46, 23-30 (2009).

64. Pandey, G. N. et al. in Contemporary Neuropsychiatry (eds Miyoshi, K., Shapiro, C. M., Gaviria M. \& Morita Y) 314-321 (Springer-Verlag: Tokyo, 2001).

65. Miller, J. M. et al. Reported childhood abuse is associated with low serotonin transporter binding in vivo in major depressive disorder. Synapse $\mathbf{6 3}$, 565-573 (2009). 
66. Gartside, S. E., Johnson, D. A., Leitch, M. M., Troakes, C. \& Ingram, C. D. Early life adversity programs changes in central 5-HT neuronal function in adulthood. Eur. J. Neurosci. 17, 2401-2408 (2003).

67. Spinelli, S. et al. Effects of early-life stress on serotonin(1A) receptors in juvenile Rhesus monkeys measured by positron emission tomography. Biol. Psychiatry 67, 1146-1153 (2010).

68. Heim, C. \& Binder, E. B. Current research trends in early life stress and depression: review of human studies on sensitive periods, gene-environment interactions, and epigenetics. Exp. Neurol. 233, 102-111 (2012).

69. Turecki G. Early-Life Adversity and Suicide Risk: The Role of Epigenetics. In: Pompili M (ed). Phenomenology of Suicide. Springer, Cham, Switzerland. 2018.

70. Brown, G. W. \& Harris, T. O. Depression and the serotonin transporter 5HTTLPR polymorphism: a review and a hypothesis concerning geneenvironment interaction. J. Affect Disord. 111, 1-12 (2008).

71. Zalsman, G. et al. Association of a triallelic serotonin transporter gene promoter region (5-HTTLPR) polymorphism with stressful life events and severity of depression. Am. J. Psychiatry 163, 1588-1593 (2006).

72. Roy, A., Hu, X. Z., Janal, M. N. \& Goldman, D. Interaction between childhood trauma and serotonin transporter gene variation in suicide. Neuropsychopharmacology 32, 2046-2052 (2007).

73. Wankerl, M. et al. Effects of genetic and early environmental risk factors for depression on serotonin transporter expression and methylation profiles. Transl. Psychiatry 4, e402 (2014).

74. Chipman, P., Jorm, A. F., Tan, X. Y. \& Easteal, S. No association between the serotonin-1A receptor gene single nucleotide polymorphism rs6295C/G and symptoms of anxiety or depression, and no interaction between the polymorphism and environmental stressors of childhood anxiety or recent stressful life events on anxiety or depression. Psychiatr. Genet. 20, 8-13 (2010).

75. Bukh, J. D. et al. Interaction between genetic polymorphisms and stressful life events in first episode depression. J. Affect Disord. 119, 107-115 (2009).

76. Weissman, M. M. \& Klerman, G. L. Sex differences and the epidemiology of depression. Arch. Gen. Psychiatry 34, 98-111 (1977).

77. Oquendo, M. A. et al. Sex differences in clinical predictors of suicidal acts after major depression: a prospective study. Am. J. Psychiatry 164, 134-141 (2007).

78. Cloninger, C. R., Christiansen, K. O. \& Reich, T. Gottesman, II. Implications of sex differences in the prevalences of antisocial personality, alcoholism, and criminality for familial transmission. Arch. Gen. Psychiatry 35, 941-951 (1978).

79. Cosgrove, K. P., Mazure, C. M. \& Staley, J. K. Evolving knowledge of sex differences in brain structure, function, and chemistry. Biol. Psychiatry $6 \mathbf{2}$, 847-855 (2007).

80. Jovanovic, $\mathrm{H}$. et al. Sex differences in the serotonin $1 \mathrm{~A}$ receptor and serotonin transporter binding in the human brain measured by PET. Neuroimage 39, 1408-1419 (2008).

81. Parsey, R. V. et al. Effects of sex, age, and aggressive traits in man on brain serotonin 5-HT1A receptor binding potential using [11CWWAY-100635. Neuroimage 16, S106-S106 (2002).

82. Soloff, P. H., Price, J. C., Mason, N. S., Becker, C. \& Meltzer, C. C. Gender, personality, and serotonin-2A receptor binding in healthy subjects. Psychiatry Res. 181, 77-84 (2010).

83. Adams, K. H. et al. A database of [(18)F]-altanserin binding to 5-HT(2A) receptors in normal volunteers: normative data and relationship to physiological and demographic variables. Neuroimage 21, 1105-1113 (2004).

84. Stein, $\mathrm{P}$. et al. The serotonin-1A receptor distribution in healthy men and women measured by PET and [carbonyl-11C]WAY-100635. Eur. J. Nucl. Med. Mol. Imaging 35, 2159-2168 (2008).

85. Kovachich, G. B., Aronson, C. E., Brunswick, D. J. \& Frazer, A. Quantitative autoradiography of serotonin uptake sites in rat brain using ${ }^{3} \mathrm{H}$ cyanoimipramine. Brain Res. 454, 78-88 (1988).

86. Underwood, M. D. \& Arango, V. Evidence for Neurodegeneration and Neuroplasticity as Part of the Neurobiology of Suicide. Biol. Psychiatry 70, 306-307 (2011).
87. Sprouse, J. S. \& Aghajanian, G. K. (-)-Propranolol blocks the inhibition of serotonergic dorsal raphe cell firing by 5-HT1A selective agonists. Eur. J. Pharmacol. 128, 295-298 (1986).

88. Stahl, S. 5HT1A receptors and pharmacotherapy. Is serotonin receptor downregulation linked to the mechanism of action of antidepressant drugs? Psychopharmacol. Bull. 30, 39-43 (1994).

89. Blakely, R. D. et al. Regulated phosphorylation and trafficking of antidepressant-sensitive serotonin transporter proteins. Biol. Psychiatry 44, 169-178 (1998).

90. Hensler, J. G. Regulation of 5-HT1A receptor function in brain following agonist or antidepressant administration. Life. Sci. 72, 1665-1682 (2003).

91. Behm, M. \& Ohman, M. RNA editing: a contributor to neuronal dynamics in the mammalian brain. Trends Genet. 32, 165-175 (2016).

92. Leiser, S. C. et al. Serotonergic regulation of prefrontal cortical circuitries involved in cognitive processing: a review of individual 5-HT receptor mechanisms and concerted effects of $5-\mathrm{HT}$ receptors exemplified by the multimodal antidepressant vortioxetine. ACS Chem. Neurosci. 6, 970-986 (2015).

93. Aznar, S. \& Hervig Mel, S. The 5-HT2A serotonin receptor in executive function: Implications for neuropsychiatric and neurodegenerative diseases. Neurosci. Biobehav. Rev. 64, 63-82 (2016).

94. Wirth, A., Holst, K. \& Ponimaskin, E. How serotonin receptors regulate morphogenic signalling in neurons. Prog. Neurobiol. 151, 35-56 (2017).

95. Burton, C. Z., Vella, L., Weller, J. A. \& Twamley, E. W. Differential effects of executive functioning on suicide attempts. J. Neuropsychiatry Clin. Neurosci. 23, 173-179 (2011).

96. Saffer, B. Y. \& Klonsky, E. D. Do neurocognitive abilities distinguish suicide attempters from suicide ideators? A systematic review of an emerging research area. Clin. Psychol.: Sci. Pract. 25, 1 (2018).

97. Olie, E. et al. Processing of decision-making and social threat in patients with history of suicidal attempt: a neuroimaging replication study. Psychiatry Res. 234, 369-377 (2015).

98. Ding, $Y$. et al. Prefrontal cortex markers of suicidal vulnerability in mood disorders: a model-based structural neuroimaging study with a translational perspective. Transl. Psychiatry 5, e516 (2015).

99. Korgaonkar, M. S., Fornito, A., Williams, L. M. \& Grieve, S. M. Abnormal structural networks characterize major depressive disorder: a connectome analysis. Biol. Psychiatry 76, 567-574 (2014).

100. Singh, M. K. et al. Anomalous gray matter structural networks in major depressive disorder. Biol. Psychiatry 74, 777-785 (2013).

101. Ferrer, I., Martinez, A., Boluda, S., Parchi, P. \& Barrachina, M. Brain banks: benefits, limitations and cautions concerning the use of post-mortem brain tissue for molecular studies. Cell Tissue Bank 9, 181-194 (2008).

102. Fowler CJ, Cowburn RF, Hardy JA, Wester P, Winblad B. Neurotransmitter Function in Post-Mortem Human Brain: An Overview. Springer Berlin Heidelberg: Berlin, Heidelberg, 1990, pp 668-674.

103. McCullumsmith, R. E. \& Meador-Woodruff, J. H. Novel approaches to the study of postmortem brain in psychiatric illness: old limitations and new challenges. Biol. Psychiatry 69, 127-133 (2011).

104. Joo, S. H. et al. Factors associated with suicide completion: a comparison between suicide attempters and completers. Asia Pac. Psychiatry 8, 80-86 (2016).

105. Davis, F. B. Relationship between suicide and attempted suicide - a review of literature. Psychiatr. Q. 41, 752-+ (1967).

106. Younes, N. et al. Attempted and completed suicide in primary care: not what we expected? J. Affect Disord. 170, 150-154 (2015).

107. Mathew, D. C. et al. Neurobiological aspects of suicide and suicide attempts in bipolar disorder. Transl Neurosci 4, 203-216 (2013).

108. Pandey, G. N. Biological basis of suicide and suicidal behavior. Bipolar Disord. 15, 524-541 (2013).

109. Balcioglu, Y. H. \& Kose, S. Neural substrates of suicide and suicidal behaviour: from a neuroimaging perspective. Psychiatry Clin. Psychopharmacol. 0, 1-15 (2018). 